\title{
Preparation of activated carbons from corn cob catalyzed by potassium salts and subsequent gasification with $\mathrm{CO}_{2}$
}

\author{
W.T. Tsai ${ }^{\text {a,* }}$, C.Y. Chang ${ }^{\text {b }}$, S.Y. Wang ${ }^{\text {b }}$, C.F. Chang ${ }^{\text {b }}$, S.F. Chien ${ }^{\text {a }}$, H.F. Sun ${ }^{\text {a }}$ \\ a Department of Environmental Engineering and Health, Chia Nan College of Pharmacy and Science, Tainan 717, Taiwan, ROC \\ ${ }^{\mathrm{b}}$ Graduate Institute of Environmental Engineering, National Taiwan University, Taipei 106, Taiwan, ROC \\ Received 6 February 2000; received in revised form 7 August 2000; accepted 7 August 2000
}

\begin{abstract}
In the present study, granular activated carbons were prepared from agricultural waste corn cob by chemical activation with potassium salts and/or physical activation with $\mathrm{CO}_{2}$. Under the experimental conditions investigated, potassium hydroxide (KOH) and potassium carbonate $\left(\mathrm{K}_{2} \mathrm{CO}_{3}\right)$ were effective activating agents for chemical activation during a ramping period of $10^{\circ} \mathrm{C} / \mathrm{min}$ and subsequent gasification (i.e., physical activation) at a soaking period of $800^{\circ} \mathrm{C}$. Large BET surface areas $\left(>1600 \mathrm{~m}^{2} / \mathrm{g}\right)$ of activated carbons were thus obtained by the combined activation. In addition, this study clearly showed that the porosity created in the acidunwashed carbon products is substantially lower than that of acid-washed carbon products due to potassium salts left in the pore structure. (C) 2001 Elsevier Science Ltd. All rights reserved.
\end{abstract}

Keywords: Activated carbon; Activation; Gasification; Corn cob; Agricultural waste; Recycling; BET surface area

\section{Introduction}

Activated carbon is a predominantly amorphous solid that has extraordinarily large internal surface area and pore volume. These unique pore structures play an important role in many different liquid- and gas-phase applications because of their association with adsorptive properties. Although most types of industrial activated carbons are produced from naturally occurring carbonaceous materials such as coal, wood and coconut shell by some form of activation process (Bansal et al., 1988; Noll et al., 1992), some agro-industrial by-products can be used as precursor materials for preparing activated carbons in the laboratory (Pollard et al., 1992; Tsai et al., 1997).

For every $100 \mathrm{~kg}$ of corn grain, $18 \mathrm{~kg}$ of corn cob is approximately produced (Bagby and Widstrom, 1987). A large quantity of corn cob thus generated remains unused as cellulosic wastes in fields and factories. This poses a serious problem not only in storage but also for

\footnotetext{
${ }^{*}$ Corresponding author. Tel.: +886-6-266-4911; fax: +886-6-2666411.

E-mail address: wwtsai@mail.chna.edu.tw (W.T. Tsai).
}

disposal. Utilization of this agricultural waste as a renewable source for energy production (Lin et al., 1995), as a carbohydrate source for producing bacterial protein (Perotti and Molina, 1988), and conversion into valuable activated carbon (Tsai et al., 1997; Aggarwal and Dollimore, 1997) has been researched and developed in the past decade.

In our previous works (Tsai et al., 1997; Tsai et al., 1998), corn cob was found to be a suitable precursor for the preparation of activated carbons by zinc chloride $\left(\mathrm{ZnCl}_{2}\right)$ activation owing to its high carbon (i.e., $45.21 \%$ ) and low ash (i.e., $0.91 \%$ ) contents. It was also demonstrated that the optimal conditions of operating pyrolysis temperature and impregnation ratio (i.e., the ratio of weight of $\mathrm{ZnCl}_{2}$ added to weight of corn cob) for the production of large surface area (greater than $1400 \mathrm{~m}^{2} / \mathrm{g}$ ) activated carbon are approximately $500^{\circ} \mathrm{C}$ and up to $175 \mathrm{wt}^{\%} \%$ at a pre-pyrolytic heating rate of $10^{\circ} \mathrm{C} / \mathrm{min}$ under an inert atmosphere of flowing nitrogen $\left(300 \mathrm{~cm}^{3} / \mathrm{min}\right.$ at STP). The advantages of this activation method over physical activation include completion in only one step and at a relative low temperature and also a yield of higher carbon content product (Philip and Girgis, 1996). It should be pointed out that the complete removal or recovery of the activating chemicals (e.g., $\mathrm{ZnCl}_{2}$ and $\mathrm{H}_{3} \mathrm{PO}_{4}$, which are the most widely used 
chemical agents) from the resulting carbon products presents significant difficulties. As a result, this chemical activation process will generate serious pollution problems related to environmental contamination with zinc compounds and ecological problems of environmental eutrophication with phosphorus compounds, which increase the overall manufacturing costs and have been limited recently in view of the environmental requirement (Jankowska et al., 1991).

The process for manufacturing activated carbons involves two steps: the carbonization of raw carbonaceous materials in an inert atmosphere and the activation of the carbonized product. Chemical activation of coke and charcoal by potassium hydroxide $(\mathrm{KOH})$ for the preparation of large surface area active carbons was reported in the 1980s (Marsh et al., 1982; Marsh et al., 1984; O'Grady and Wennerberg, 1986). Since then, there have been a number of works describing $\mathrm{KOH}$ or other potassium salts activation to obtain the carbons (Laine and Calafat, 1991; Laine and Yunes, 1992; Verheyen et al., 1995; Hu and Vansant, 1995; Ahmadpour and Do, 1996; Otowa et al., 1997; Ahmadpour and Do, 1997; Evans et al., 1999; Hu and Srinivasan, 1999). In addition, potassium salts are known to catalyze the partial gasification of carbonaceous materials with $\mathrm{CO}_{2}$ (Walker et al., 1968; Laine and Calafat, 1991). These features suggest a possible application of such chemical activators for the preparation of largesurface-area activated carbons from corn cob. The chemical activation with potassium salts could be also considered as a cleaner production technology while compared to that with $\mathrm{ZnCl}_{2}$ or $\mathrm{H}_{3} \mathrm{PO}_{4}$. The objective of the present work attempted to investigate the preparation of activated carbon from corn cob. The pyrolysis process involved impregnation of the precursor with different potassium salts and activation by passing $\mathrm{CO}_{2}$ as the activating gas at the specified temperature. Some of these results were also compared with those obtained by chemical activation with effective potassium salts using $\mathrm{N}_{2}$ gas. In addition, we studied the influence of acid-washing vs no acid-washing on the physical property of the carbon products under the activation of potassium salts $/ \mathrm{CO}_{2}$.

\section{Methods}

The apparatus and experimental methods employed in the present work are similar to those for the chemical activation with $\mathrm{ZnCl}_{2}$ as reported previously (Tsai et al., 1997; Tsai et al., 1998). Corn cob was obtained from a Chia Yi production zone in Taiwan, and then crushed and sieved to $1.0-2.0 \mathrm{~mm}$. Twenty grams of this material was mixed with $200 \mathrm{ml}$ of the potassium solution (e.g. $\mathrm{KOH}$ or $\mathrm{K}_{2} \mathrm{CO}_{3}$ ) of known concentration. Impregnation was carried out at approximately $80^{\circ} \mathrm{C}$ on a stirrer/ hot plate with boiler-reflux condenser for $2 \mathrm{~h}$. Afterward, the sample solution was filtered in a vacuum filter flask and dried overnight at $120^{\circ} \mathrm{C}$.

Prior to activation experiments, the influence of the flow rates (i.e., 200, 500 and $800 \mathrm{~cm}^{3} / \mathrm{min}$ at STP) of nitrogen and the heating rates (i.e., 5,10 and $20^{\circ} \mathrm{C} / \mathrm{min}$ ) on the carbon products were studied. The results of the preliminary experiments indicate that these activation parameters are not significant factors affecting the porosity of the final carbon products. To assure the reliability of carbon products and measurement data, the raw materials were well mixed and sampled for the activation experiment. In addition, prior to the measurement of physical properties of the carbon products, the calibration of the analyzer was performed by standard operational procedures. Also, for the purpose of reproducibility test, the BET surface area $348 \pm 21 \mathrm{~m}^{2} / \mathrm{g}$ (i.e., mean \pm standard deviation) of the carbon sample, conducted at an activation temperature of $500^{\circ} \mathrm{C}$ and a $\mathrm{N}_{2}$ flow of approximately $500 \mathrm{~cm}^{3} / \mathrm{min}$, was obtained for three measurements. Based on the above operations, one sample was used for each experiment in the present work. Thus, pyrolysis temperature was increased at a ramp rate of $10^{\circ} \mathrm{C} / \mathrm{min}$ in a $\mathrm{N}_{2}$ flow $\left(200 \mathrm{~cm}^{3} / \mathrm{min}\right.$ at STP) as reported previously (Tsai et al., 1997; Tsai et al., 1998), then switched to $\mathrm{CO}_{2}$ flow $\left(200 \mathrm{~cm}^{3} / \mathrm{min}\right.$ at STP) after reaching the specified temperature (i.e., $800^{\circ} \mathrm{C}$ ), which was adopted for the catalytic experiments of Laine and Calafat (1991). After activation with $\mathrm{CO}_{2}$ for $1 \mathrm{~h}$, cooling to room temperature was carried out under $\mathrm{N}_{2}$ flow before taking the sample for washing with $3 \mathrm{~N}$ hot $\mathrm{HCl}$ solution. The acid washed sample was filtered in a vacuum flask followed by washing repeatedly with $80^{\circ} \mathrm{C}$ distilled water to remove residues attached to the resulting activated carbon. Finally, the product of activated carbon was dried overnight at $120^{\circ} \mathrm{C}$ and placed in a desiccator for further analyses. For preliminary comparisons, some of the activated carbons were also prepared by chemical activation with $\mathrm{KOH}$ or $\mathrm{K}_{2} \mathrm{CO}_{3}$ in the present study. The heating procedure was similar to that employed as mentioned, but only using $200 \mathrm{~cm}^{3} /$ $\min \mathrm{N}_{2}$.

BET surface area analyses of the resulting activated carbons were measured as described previously (Tsai et al., 1997; Tsai et al., 1998). Nitrogen adsorption-desorption isotherms at $-196^{\circ} \mathrm{C}$ were obtained employing the Micromeritics ASAP 2000 and BET surface area was determined by means of the standard BET equation applied in a relative pressure range from 0.06 to 0.3 (Gregg and Sing, 1982; Lowell and Shields, 1991). The values of $0.81 \mathrm{~g} / \mathrm{cm}^{3}$ and $16.2 \times 10^{-20} \mathrm{~m}^{2}$ were used for the density of liquid nitrogen at $-196^{\circ} \mathrm{C}$ and the molecular area of adsorbate nitrogen, respectively, in the measurements of BET surface area. The total pore volumes $\left(V_{t}\right)$ were estimated to be the liquid volumes of $\mathrm{N}_{2}$ at a high relative pressure of 0.96 . The true density $\left(\rho_{\mathrm{s}}\right)$ of 
the sample was measured by a helium displacement method with a pycnometer (Micromeritics, AccuPyc 1330) (Lowell and Shields, 1991), where the measurement was repeated ten times for each sample. The particle density $\left(\rho_{\mathrm{p}}\right)$ was thus calculated from $V_{t}$ and $\rho_{\mathrm{s}}$ (Smith, 1981)

$\rho_{\mathrm{p}}=1 /\left(V_{t}+1 / \rho_{\mathrm{s}}\right)$.

Therefore, the particle porosity $\left(\varepsilon_{\mathrm{p}}\right)$ can be computed from $\rho_{\mathrm{s}}$ and $\rho_{\mathrm{p}}$.

$\varepsilon_{\mathrm{p}}=1-\rho_{\mathrm{p}} / \rho_{\mathrm{s}}$.

Analysis of main elements for carbon products was performed by using a $\mathrm{CHN}-\mathrm{O}$ rapid analyzer (Heraeus Co.) for two measurements. The inductively coupled plasma-atomic emission spectrometer (ICP-AES) of ICAP 9000 (JARREL-ASH Co.) was used to determine the trace elements for three measurements.

All characterization determinations of the resulting activated carbons except surface area, pore volume and pore size distribution from $\mathrm{N}_{2}$ adsorption-desorption measurement were replicated at least two times. By using the Microsoft Excel ${ }^{\circledast}$ computer package, the procedures most commonly used to estimate the statistical parameters (i.e., mean and standard deviation) of measurement data were made.

\section{Results and discussion}

From the data in Table 1, it is clear that the potassium hydroxide $(\mathrm{KOH})$ and potassium carbonate $\left(\mathrm{K}_{2} \mathrm{CO}_{3}\right)$ are effective catalysts for activation of the corn cob among the potassium compounds studied. It is also noted that the BET surface area of the activated carbon prepared without catalyst was smaller than that with catalyst. In order to study the substantial influence of $\mathrm{CO}_{2}$ gasification on the porosity development, the chemical activations of corn cob impregnated with $15 \mathrm{wt} \% \mathrm{KOH}$ and $37.5 \mathrm{wt} \% \mathrm{~K}_{2} \mathrm{CO}_{3}$ were carried out at a temperature of $800^{\circ} \mathrm{C}$ in a $\mathrm{N}_{2}$

Table 1

BET surface area of activated carbons produced from corn cob impregnated with different potassium compounds (10.5 wt \% K), employing $\mathrm{CO}_{2}$ flow at $800^{\circ} \mathrm{C}$ for $1 \mathrm{~h}$

\begin{tabular}{lcl}
\hline K-compounds & $\begin{array}{l}\text { BET surface area } \\
\left(\mathrm{m}^{2} / \mathrm{g}\right)\end{array}$ & $\begin{array}{l}\text { Pyrolysis yield }^{\mathrm{a}} \\
(\%)\end{array}$ \\
\hline unimpregnated & 437 & 22.9 \\
$\mathrm{KCl}$ & 490 & 27.6 \\
$\mathrm{~K}_{3} \mathrm{PO}_{4}$ & 732 & 23.1 \\
$\mathrm{KNO}_{3}$ & 903 & 20.4 \\
$\mathrm{~K}_{2} \mathrm{CO}_{3}$ & 1266 & 18.7 \\
$\mathrm{KOH}$ & 1682 & 14.7 \\
\hline
\end{tabular}

${ }^{a}$ The yield is defined as the ratio of the mass of impregnated sample to that of activated product. atmosphere. The condition of the impregnation ratios selected in the present study was based on the results of the previous experiments, where the carbon products could not be obtained at higher impregnation ratios (i.e., $20 \mathrm{wt} \% \mathrm{KOH}$ and $50 \mathrm{wt} \% \mathrm{~K}_{2} \mathrm{CO}_{3}$ ) due to serious sintering or excess burn-off (Laine and Calafat, 1991). In Table 2 the BET surface areas of carbon products obtained by chemical activation accompanied with $\mathrm{N}_{2}$ are compared with those of chemically and subsequent physically activated samples with $\mathrm{CO}_{2}$. The results show that the process of combined chemical and physical activation is superior to that of chemical activation only.

The nitrogen adsorption isotherms on the resulting activated carbons are shown in Fig. 1. It is seen that the knee of the adsorption isotherm is sharp and its plateau is also horizontal with nearly no hysteresis. Evidently, the carbon product thus obtained is of type I according to the Brunauer, Deming, Deming and Teller (BDDT) classification for the types of the adsorption isotherm (Gregg and Sing, 1982). The major uptake occurs at low relative pressures (less than 0.1), indicating the formation of highly porous material with narrow pore size distribution that is essentially microporous as listed in Table 3. It should be noted that the interaction potential in a microporous solid might be strong enough to bring about a nearly complete filling of pores at a quite low relative pressure (Laine and Calafat, 1991).

The main effect of gasification with $\mathrm{CO}_{2}$ is the creation and widening of the existing pores, indicating the increase in adsorptive properties such as the BET surface area. As discussed by Laine and Calafat (1991) in the preparation of activated carbons from coconut shell with potassium compounds, the relatively large surface area found in the $\mathrm{K}_{2} \mathrm{CO}_{3}$ - and $\mathrm{KOH}$-impregnated samples could be attributed to carbon gasification with the gaseous products (i.e., $\mathrm{CO}_{2}$ and $\mathrm{H}_{2} \mathrm{O}$ ) of the decomposition of potassium compounds and partial reaction of the salts with the cellulose constituting corn cob.

Table 2

Effects of $\mathrm{CO}_{2}$ on BET surface area of the resulting activated carbon prepared from corn cob with activation using impregnation ratio of $15 \mathrm{wt} \%$ and $37.5 \mathrm{wt} \%$ for $\mathrm{KOH}$ and $\mathrm{K}_{2} \mathrm{CO}_{3}$, respectively

\begin{tabular}{|c|c|c|}
\hline \multicolumn{2}{|c|}{ Carbon samples } & \multirow[t]{2}{*}{ BET surface area $\left(\mathrm{m}^{2} / \mathrm{g}\right), S_{\mathrm{BET}}$} \\
\hline $\begin{array}{l}\text { Chemical } \\
\text { activator }\end{array}$ & Gas flow & \\
\hline $\mathrm{KOH}$ & $\mathrm{N}_{2}$ & 369 \\
\hline $\mathrm{KOH}$ & $\mathrm{CO}_{2}$ & $1682^{\mathrm{a}}$ \\
\hline $\mathrm{K}_{2} \mathrm{CO}_{3}$ & $\mathrm{~N}_{2}$ & 506 \\
\hline $\mathrm{K}_{2} \mathrm{CO}_{3}$ & $\mathrm{CO}_{2}$ & $1541^{\mathrm{b}}$ \\
\hline
\end{tabular}

${ }^{\mathrm{a}}$ The carbon yield, defined as the ratio of the mass of impregnated sample to that of activated product, is $14.7 \%$.

${ }^{\mathrm{b}}$ The carbon yield is $17.4 \%$. 

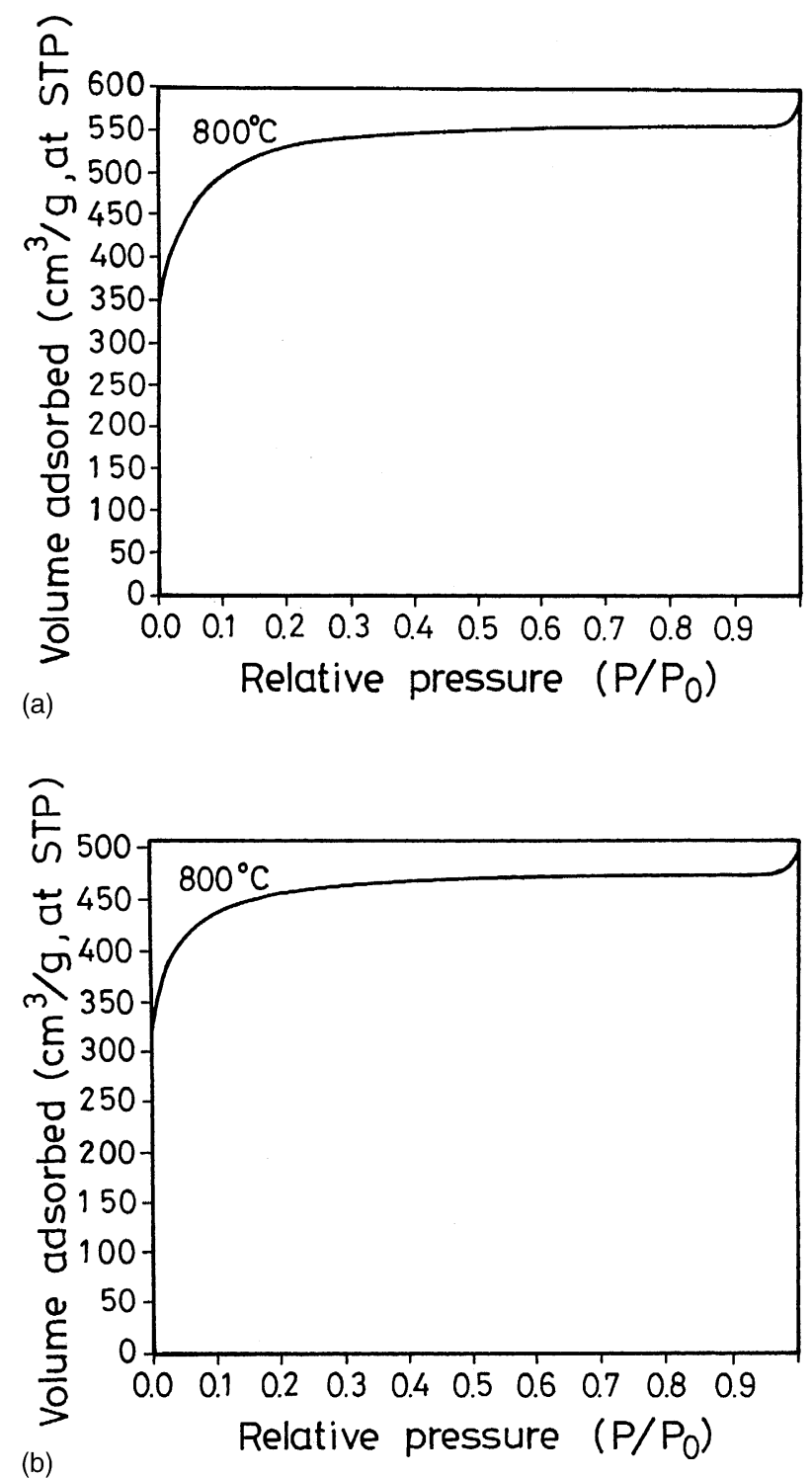

Fig. 1. Adsorption isotherms of nitrogen of the resulting activated carbons produced at activation temperatures of $800^{\circ} \mathrm{C}$, impregnation ratios of (a) $15 \mathrm{wt} \% \mathrm{KOH}$ and (b) $37.5 \mathrm{wt} \% \mathrm{~K}_{2} \mathrm{CO}_{3}$, followed by soaking time of $1 \mathrm{~h}$ under flow of $\mathrm{CO}_{2}$.

From the view of industrial use, the properties of activated carbon, such as total pore volume, true density, particle density, particle porosity and major/trace element contents, are also important. The results of these properties of resulting activated carbons are given in Table 4. Based on the data in Table 4, it appears that the carbon is characteristic of high porosity and possesses high true density compared with those (i.e., 2.24 and $2.22 \mathrm{~g} / \mathrm{cm}^{3}$, respectively) of commercial activated carbons BPL and PCB (Calgon Co., U.S.A.) (Tsai and Chang, 1994a). It is also seen from Table 4 that the carbon products contain nearly $90 \mathrm{wt} \%$ of carbon, which are approximate to those (i.e., 87.88 and 94.85 $\mathrm{wt} \%$, respectively) of carbons BPL and PCB (Tsai and Chang, 1994b). However, based on the major trace metal composition of carbon products (Table 4), it can also be seen that the $\mathrm{Si}$ and $\mathrm{Al}$ elements are the two highest sources of trace metal.

As mentioned in the experimental section, after the combined chemical and physical activation the crude carbon products were subjected to washing with hydrochloric acid and distilled water. It is known that washing with acid removes the alkali and alkaline earth metals, and washing with water removes the basic and water-soluble components in the carbon (Ahmadpour and Do, 1996). Thus, the final carbon products obtained by washing will yield well-developed porosity in the carbon structure. This point had been confirmed in our study of corn cob employing the combined activation. The test was performed on two samples with the impregnation ratios of $20 \mathrm{wt} \% \mathrm{KOH}$ and $25 \mathrm{wt} \% \mathrm{~K}_{2} \mathrm{CO}_{3}$. The results of BET surface area before and after washing of samples are presented in Table 5. The results clearly show that the approximate $50 \%$ of porosity (reflected by the BET surface area) created in the carbon samples should be occupied by potassium salts in the structure. Small surface areas of the unwashed carbons are because of potassium salts left in the carbon products, blocking pore entrances to the nitrogen molecules based on the analysis of adsorption and desorption isotherms of nitrogen for determining BET surface area. Also, the values of BET surface area of the resulting activated carbons increase with the increase in the impregnation ratio of $\mathrm{K}_{2} \mathrm{CO}_{3}$ activating agent from the data in Tables 1, 2 and 5, i.e., $1266 \mathrm{~m}^{2} / \mathrm{g}(21.2 \mathrm{wt} \%$ of $\mathrm{K}_{2} \mathrm{CO}_{3}$ or $\left.10.5 \mathrm{wt} \% \mathrm{~K}\right)<1424 \mathrm{~m}^{2} / \mathrm{g}\left(25 \mathrm{wt} \%\right.$ of $\left.\mathrm{K}_{2} \mathrm{CO}_{3}\right)$ $<1541 \mathrm{~m}^{2} / \mathrm{g}\left(37.5 \mathrm{wt} \%\right.$ of $\left.\mathrm{K}_{2} \mathrm{CO}_{3}\right)$. This result is consistent with the result reported for the chemical activation of $\mathrm{ZnCl}_{2}$ (Tsai et al., 1997).

In conclusion, the combined chemical and physical activation process was attempted to prepare activated carbon from corn cob catalyzed by potassium salts and subsequent gasification with $\mathrm{CO}_{2}$ in the present study. It was found that $\mathrm{KOH}$ and $\mathrm{K}_{2} \mathrm{CO}_{3}$ were effective catalysts for the activation with $\mathrm{CO}_{2}$ among all the potassium compounds studied. The carbon products thus obtained possess a large surface area of about $1700 \mathrm{~m}^{2} / \mathrm{g}$. The BET surface areas of the combined activated carbon products were also compared with those obtained purely by chemical activation. In addition, the washing treatment was an important factor affecting the pore entrances and thus the physical properties of the resulting carbon products. Due to their large adsorption capacity (i.e., large BET surface area), low cost (i.e., agricultural waste) and cleaner production process (i.e., $\mathrm{KOH} / \mathrm{K}_{2} \mathrm{CO}_{3}$ instead of $\mathrm{ZnCl}_{2}$ or $\left.\mathrm{H}_{3} \mathrm{PO}_{4}\right)$, the corn cob-derived activated carbon products may offer potential as substitutes for commercial activated carbons. 
Table 3

List of adsorption pore distribution of the resulting carbons ${ }^{\mathrm{a}}$

\begin{tabular}{|c|c|c|c|}
\hline \multicolumn{2}{|c|}{ Activated carbon $(15 \mathrm{wt} \% \mathrm{KOH})$} & \multicolumn{2}{|c|}{ Activated carbon $\left(37.5 \mathrm{wt} \% \mathrm{~K}_{2} \mathrm{CO}_{3}\right)$} \\
\hline Pore diameter $(D, \AA)$ & Pore volume ${ }^{\mathrm{b}}\left(V, \mathrm{~cm}^{3} / \mathrm{g}\right)$ & Pore diameter $(D, \AA)$ & Pore volume ${ }^{\mathrm{b}}\left(V, \mathrm{~cm}^{3} / \mathrm{g}\right)$ \\
\hline 2120 & 0.040 & 2160 & 0.004 \\
\hline 805 & 0.007 & 830 & 0.003 \\
\hline 420 & 0.001 & 518 & 0.001 \\
\hline 215 & 0.002 & 216 & 0.003 \\
\hline 150 & 0.004 & 122 & 0.005 \\
\hline 120 & 0.007 & 95 & 0.013 \\
\hline 97 & 0.021 & 68 & 0.022 \\
\hline 52 & 0.047 & 52 & 0.031 \\
\hline 42 & 0.086 & 41 & 0.056 \\
\hline 32 & 0.140 & 33 & 0.102 \\
\hline 27 & 0.325 & 26 & 0.207 \\
\hline 22 & 0.955 & 21 & 0.551 \\
\hline
\end{tabular}

a Produced at activation temperature of $800^{\circ} \mathrm{C}$, impregnation ratio of $15 \mathrm{wt} \% \mathrm{KOH}$ and $37.5 \mathrm{wt} \% \mathrm{~K}_{2} \mathrm{CO}_{3}$, respectively, followed by soaking time of $1 \mathrm{~h}$ under $\mathrm{CO}_{2}$ flow.

${ }^{\mathrm{b}}$ Performed as the form of $\mathrm{d} V / \mathrm{d} \log (D)$.

Table 4

Physical properties and element analysis of resulting activated carbons prepared from corn cob with activation using impregnation ratio of $15 \mathrm{wt} \%$ $\mathrm{KOH}$ and $375 \mathrm{wt} \% \mathrm{~K}_{2} \mathrm{CO}_{3}$, and employing $\mathrm{CO}_{2}$ flow at $800^{\circ} \mathrm{C}$ for $1 \mathrm{~h}$

\begin{tabular}{|c|c|c|c|}
\hline \multicolumn{2}{|c|}{ Physical properties/element analysis } & \multicolumn{2}{|l|}{ Carbon products } \\
\hline & & $15 \mathrm{wt} \% \mathrm{KOH} / \mathrm{CO}_{2}$ & $37.5 \mathrm{wt} \% \mathrm{~K}_{2} \mathrm{CO}_{3} / \mathrm{CO}_{2}$ \\
\hline \multirow{8}{*}{$\begin{array}{l}\text { Total pore volume }\left(\mathrm{cm}^{3} / \mathrm{g}\right. \\
\text { True density }\left(\mathrm{g} / \mathrm{cm}^{3}\right), \rho_{\mathrm{s}} \\
\text { Particle density }\left(\mathrm{g} / \mathrm{cm}^{3}\right) \text {, } \\
\text { Particle porosity }(-), \varepsilon_{\mathrm{p}} \\
\text { Major elements }{ }^{\mathrm{d}}(\mathrm{wt} \%)\end{array}$} & & 0.84 & 0.74 \\
\hline & & $2.506 \pm 0.004$ & $2.417 \pm 0.004$ \\
\hline & & 0.82 & 0.86 \\
\hline & & 0.673 & 0.645 \\
\hline & $\mathrm{C}$ & $89.20 \pm 0.59$ & $85.11 \pm 0.53$ \\
\hline & $\mathrm{H}$ & $0.77 \pm 0.08$ & $0.99 \pm 0.13$ \\
\hline & $\mathrm{N}$ & $0.54 \pm 0.01$ & $1.58 \pm 0.01$ \\
\hline & $\mathrm{O}$ (by diff.) & 9.49 & 12.32 \\
\hline \multirow[t]{5}{*}{ Trace elements $^{\mathrm{e}}(\mu \mathrm{g} / \mathrm{g})$} & $\mathrm{Si}$ & $1176 \pm 15$ & $>1000$ \\
\hline & $\mathrm{Al}$ & $171 \pm 6$ & $236 \pm 8$ \\
\hline & $\mathrm{K}$ & $115 \pm 5$ & $201 \pm 9$ \\
\hline & $\mathrm{Fe}$ & $1.9 \pm 0.5$ & $82 \pm 3.3$ \\
\hline & $\mathrm{Pb}$ & $4.4 \pm 0.2$ & $12 \pm 0.7$ \\
\hline
\end{tabular}

${ }^{\text {a }}$ The true density $\left(\rho_{\mathrm{s}}\right)$ was measured by helium displacement method with a pycnometer. The data denote the mean \pm standard deviation for ten determinations.

${ }^{\mathrm{b}}$ The particle density $\left(\rho_{\mathrm{p}}\right)$ is calculated from the total pore volume $\left(V_{t}\right)$ and true density $\left(\rho_{\mathrm{s}}\right)\left(\right.$ Smith, 1981), i.e., $\rho_{\mathrm{p}}=1 /\left(V_{t}+1 / \rho_{\mathrm{s}}\right)$.

${ }^{\mathrm{c}}$ The particle porosity $\left(\rho_{\mathrm{p}}\right)$ is computed from the total pore volume $\left(V_{t}\right)$ and particle density $\left(\rho_{\mathrm{p}}\right)\left(\right.$ Smith, 1981), i.e., $\varepsilon_{\mathrm{p}}=1-\rho_{\mathrm{p}} / \rho_{\mathrm{s}}$

${ }^{\mathrm{d}}$ The data denote the mean \pm standard deviation for two determinations.

${ }^{\mathrm{e}}$ The data denote the mean \pm standard deviation for three determinations.

Table 5

Variation in BET surface area of carbon products prepared by $\mathrm{KOH} / \mathrm{CO}_{2}$ and $\mathrm{K}_{2} \mathrm{CO}_{3} / \mathrm{CO}_{2}$ activation before and after washing

\begin{tabular}{lllc}
\hline Carbon samples & & Treatment & $\begin{array}{c}\text { BET surface area } \\
\left(\mathrm{m}^{2} / \mathrm{g}\right), S_{\mathrm{BET}}\end{array}$ \\
\hline Chemical activator & Impregnation ratio & Unwashed & 779 \\
$\mathrm{KOH}$ & $20 \mathrm{wt} \%$ & Washed & $1628^{\mathrm{a}}$ \\
& $20 \mathrm{wt} \%$ & Unwashed & 846 \\
$\mathrm{~K}_{2} \mathrm{CO}_{3}$ & $25 \mathrm{wt} \%$ & Washed & $1424^{\mathrm{b}}$ \\
& $25 \mathrm{wt} \%$ & & \\
\hline
\end{tabular}

\footnotetext{
${ }^{a}$ The carbon yield is $15.8 \%$

${ }^{\mathrm{b}}$ The carbon yield is $18.0 \%$.
} 


\section{Acknowledgements}

This research was supported by National Science Council (NSC), Taiwan, under contract number NSC 87-2211-E-041-005.

\section{References}

Aggarwal, P., Dollimore, D., 1997. The production of active carbon from corn cobs by chemical activation. J. Therm. Anal. 50, 525531 .

Ahmadpour, A., Do, D.D., 1996. The preparation of active carbons from coal by chemical and physical activation. Carbon 34, $471-479$.

Ahmadpour, A., Do, D.D., 1997. The preparation of activated carbon from macadamia nutshell by chemical activation. Carbon 35, $1723-1732$.

Bagby, M.O., Widstrom, N.W., 1987. Biomass uses and conversions. In: Watson, S.A., Ramstad, P.E., (Eds.). Corn: Chemistry and Technology, American Association of Cereal Chemists Inc., St. Paul, MN, USA, pp. 575-590.

Bansal, R.C., Donnet, J.B., Stoeckli, F., 1988. Active Carbon. Marcel Dekker, New York.

Evans, M.J.B., Halliop, E., MacDonald, J.A.F., 1999. The production of chemically-activated carbon. Carbon 37, 269-274.

Gregg, S.J., Sing, K.S.W., 1982. Adsorption Surface Area and Porosity, second ed. Academic Press, New York.

Hu, Z., Srinivasan, M.P., 1999. Preparation of high-surface-area activated carbons from coconut shell. Microporous and Mesoporous Mater. 27, 11-18.

Hu, Z., Vansant, E.F., 1995. Chemical activation of elutrilithe producing carbon-aluminosilicate composite adsorbent. Carbon $33,1293-1300$.

Jankowska, H., Swiatkowski, A., Choma, J., 1991. Active Carbon. Ellis Horwood, Chichester, England.

Laine, J., Calafat, A., 1991. Factors affecting the preparation of activated carbons from coconut shell catalized by potassium. Carbon 29, 949-953.

Laine, J., Yunes, S., 1992. Effect of the preparation method on the pore size distribution of activated carbon from coconut shell. Carbon 30, 601-604.

Lin, J.L., Keener, H.M., Essenhigh, R.H., 1995. Pyrolysis and combustion of corncobs in a fluidized bed: measurement and analysis of behavior. Combust. Flame 100, 271-282.
Lowell, S., Shields, J.E., 1991. Powder Surface Area and Porosity, third ed. Chapman and Hall, New York.

Marsh, H., Crawford, D.C., O'Grady, T.M., Wennerberg, A., 1982. Carbons of high surface area. a study by adsorption and high resolution electron microscopy. Carbon 20, 419-426.

Marsh, H., Yan, D.S., O'Grady, T.M., Wennerberg, A., 1984. Formation of active carbons from cokes using potassium hydroxide. Carbon 22, 603-611.

Noll, K.E., Gounaris, V., Hou, W.S., 1992. Adsorption Technology for Air and Water Pollution Control. pp. 3-6, Lewis, Chelsea, MI, USA.

O'Grady, T.M., Wennerberg, A., 1986. High-surface-area Active carbon. In: Bacha, J.D., Newman, J.W., White, J.L., (Eds.), Petroleum-Derived Carbons, ACS Symp. Ser. 303, ACS, Washington, DC, pp. 302-309.

Otowa, T., Nojima, Y., Miyazaki, T., 1997. Development of KOH activated high surface area carbon and its application to drinking water purification. Carbon 35, 1315-1319.

Perotti, N.I., Molina, O.E., 1988. Corn cob as a bacterial substrate for the production of forage protein. Biol. Wastes 26, 125-131.

Philip, C.A., Girgis, B.S., 1996. Adsorption characteristics of microporous carbons from apricot stones activated by phosphoric acid. J. Chem. Tech. Biotechnol. 67, 248-254.

Pollard, S.J.T., Fowler, G.D., Sollars, C.J., Perry, R., 1992. Low-cost adsorbents for waste and wastewater treatment: a review. Sci. Total Environ. 116, 31-52.

Smith, J.M., 1981. Chemical Engineering Kinetics, third ed. McGrawHill, New York.

Tsai, W.T., Chang, C.Y., 1994a. Adsorption of methylene chloride vapor on activated carbons. J. Chem. Tech. Biotechnol. 61, $145-151$.

Tsai, W.T., Chang, C.Y., 1994b. Surface chemistry of activated carbons and its relevance for effects of relative humidity on adsorption of chlorinated organic vapors. Chemosphere 29, 2507-2515.

Tsai, W.T., Chang, C.Y., Lee, S.L., 1997. Preparation and characterization of activated carbons from corn cob. Carbon 35, 1198-1200.

Tsai, W.T., Chang, C.Y., Lee, S.L., 1998. A low cost adsorbent from agricultural waste corn cob by zinc chloride activation. Bioresource Technol. 64, 211-217.

Verheyen, V., Rathbone, R., Jagtoyen, M., Derbyshire, F., 1995. Activated extrudates by oxidation and $\mathrm{KOH}$ activation of bituminous coal. Carbon 33, 763-772.

Walker, P.L., Jr, Shelef, M., Anderson, R.A., 1968. Catalysis of carbon gasification. In: Walker, P.L., Jr. (Ed.), Chemistry and Physics of Carbon, vol. 4, Marcel Dekker, New York, pp. 287-383. 